Lask1, Harold J., Where Do We Go From Here? New York: The Viking Press, 1940, pp. 192, \$1.75.

Maynard, Theodore, Queen Elizabeth, Milwaukee: The Bruce Publishing Company, 1940, pp. xv, 399, $\$ 4.00$.

McCully, Bruce Tiebout, Ph.D., English Education and the Origins of Indian Nationalism, New York: Columbia University Press, 1940, pp. 418, \$4.50.

OstergaArd, Soren K., Into Abundance, Chicago: Willett, Clark \& Company, 1940, pp. $x, 154, \$ 1.50$.

Salter, J. T., The Pattern of Politics, New York: The Macmillan Company, 1940, pp. xiv, 246, $\$ 2.25$.

Schumpeter, E. B., G. C. Allen, M. S. Gordan, and E. F. Penrose, The Industrialization of Japan \& Manchukuo, 1930-1940: Population Raw Materials and Industry. New York: The Macmillan Company, 1940, pp. xxviii, 944, \$7.50.

Sforza, Count Carlo, Fifty Years of $W$ ar and Diplomacy in the Balkans, New York: Columbia University Press, 1940, pp. x, 195, \$2.75.

SpIegel, Henry W., Land Tenure Policies, Chapel Hill: The University of North Carolina Press, 1941, pp. xii, 171, \$3.00.

Wallace, Schuyler C., Federal Departmentalization, New York: Columbia University Press, 1941, pp. ix, 251, $\$ 2.75$.

Ware, Caroline F., The Cultural Approach to History, New York: Columbia University Press, 1940, pp. ix, 359, \$3.50.

The Review of Politics, without neglecting the analysis of institutions and techniques, is primarily interested in the philosophical and historical approach to political realities.

All manuscripts, books for review, exchanges, inquiries, and subscriptions, should be addressed to the Editors, The Review of Politics, Notre Dame, Indiana.

Opinions expressed in the articles printed in THE REview of Politics are those of the authors alone and are not necessarily opinions held by the editors.

The contents of this publication cannot be reissued or republished in any form without special permission from the Editors. 
The publishers of Philosophic Abstracts take pleasure in announcing for Summer 1941 publication

\title{
THE DICTIONARY OF PHILOSOPHY
}

Although embraced in one volume, the dictionary covers metaphysies, ethics, epistemology, logic, philosophy of religion. esthetics. philosophy of law. philosophy of education, social philosophy and philosophical psychology. Special emphasis has been placed on the definition of basic concepts and terms yermane to the contemporary schools of philosophy. logical positivism, dialectical mater. ialism, mathematical logic, neo-scholasticism, philosophy of science, Chinese, Jewish and Indian philosophy.

The DICTIONARY OF PHILOSOPHY is edited by Dagolnert $D$. Runes with the collaboration of Alonzo Church. Rudolf Carnap. G. Watts Cunningham. Edgar Sheffield Brightman, Irwin Edman, Rudolf Allers, A. C. Ewing. Ralph Tyler Flewelling. Jorgen Jorgensen, Ledger Wood. William Marias Malisoff, Carl G. Hemnel, B. A. G. Fuller, A. Cornelius Benjamin, Hunter Guthrie, Wilbur Long, V. J. McGill, A. C. Pegis, Glenn R. Morrow, Jeseph Ratner. Wendell T. Bush, Dorion Cairns, James K. Feibleman, Faul $\Lambda$. Schillp, Paul Weiss and a number of other scholars.

Applications for further literature, as well as other communications, should be addressed to:

\section{PHILOSOPHIC ABSTRACTS}

15 East 40th Street

New York City

\section{Readers of the REVIEW OF POLITICS Should also Read}

\section{BLACKFRIARS}

\section{The Monthly Review Edited By \\ The English Dominicans}

It seeks to give in the English tongue what its virile French contemporaries "La Vie Spirituelle." and "La Vie Intellectuelle" have been giving to the French reading public:

\section{THE SPIRITUAL and CULTURAL BACKGROUND TO POLITICS and SOCIETY}

\author{
$\$ 3$ for One Year's Subscription from
}

BASIL BLACKWELL, LTD.

Broad St., Oxford, England 


\title{
University of Notre Dame
}

\author{
Notre Dame, Indiana
}

\section{The Department of Politics}

A limited number of scholarships for the degree of Master of Arts and of Doctor of Philosophy will be offered from 1941 to 1943.

Application should be filed by May Ist with the Reverend Philip S. Moore, C.S.C., Secretary of the Graduate Committee, Notre Dame, Indiana.

\section{DEMOCRACY OR ANARCHY?}

\section{A Study of Proportional Representation}

\author{
By F. A. Hermens
}

Associate Professor of Politics, University of Notre Dame

\section{Preface by C. J. Friedrich}

Professor of Government, Harvard University

The central theme of this book is that democracy has in most countries given way to dictatorship because it has stressed liberty to the extent of ignoring the need for authority.

Tentative date of publication: May 20, 1941. About 400 pages. Introductory price (for orders received by May 20th) $\$ 3.25$. List price: $\$ 4.00$.

Address orders to

\section{THE REVIEW OF POLITICS}

University of Notre Dame, Notre Dame, Indiana 